\title{
TOMORROW'S PROFESSOR TODAY
}

\author{
TRACKING PERCEPTIONS OF PREPARATION FOR \\ FUTURE FACULTY COMPETENCIES
}

\author{
Michael S. Palmer, Deandra Little \\ University of Virginia
}

The University of Virginia's Tomorrow's Professor Today (TPT) program is a broadly conceived graduate student professional development program designed to facilitate the transition from student to academic professional. Begun in 2005 in response to the recommendations of a number of national reform initiatives, TPT focuses on improving preparedness in three key areas: teaching, research, and service. We describe the key elements of the program and ongoing assessment efforts. Pre- and postprogram participant surveys from the first eight years show that TPT is improving perceptions of preparedness in twenty-one competencies tracked; follow-up studies support long-term impact.

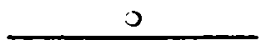

In 2005, the University of Virginia (UVa) Teaching Resource Center developed the Tomorrow's Professor Today (TPT) program, a graduate student professional development program designed to facilitate the transition from student to academic professional. Our program design was

We thank Tatiana Mathews and Ashley McHugh for help with data entry and Melissa Hurst, director of the University of Virginia Graduate Career Development, for statistical analysis of pre- and post-TPT survey data. 
influenced by needs expressed locally by UVa graduate students, as well as research emerging from a number of national reform initiatives (Fagan $\&$ Suedkamp Wells, 2004; Gaff, 2002; Gaff, Pruitt-Logan, \& Weibl, 2000; Goldsmith, Haviland, Daily, \& Wiley, 2004; Nyquist \& Woodford, 2000; Walker, 2004; Walker et al., 2008) and research focused on areas of mismatch between what junior faculty are expected to do and their doctoral training (Adams, 2002; Austin, 2002; Austin \& Wulff, 2004; Berberet, 2008; Gaff, 2002; Wulff \& Austin, 2004). Overall, these studies recommended increasing support for graduate students to better prepare them for a wide range of faculty roles and help them more clearly understand what an academic career entails. Specifically they recommend that teaching preparation be strengthened and that doctoral students be given more opportunities to explore innovative teaching techniques and fine-tune their teaching skills. Of the responsibilities new faculty take on, teaching often demands the most immediate attention and consumes the most time and energy. Finally, they advocate more robust and better-integrated professional development experiences for graduate students.

In response, we designed our program to improve doctoral student preparedness in three key areas-teaching, research, and service-and we divided program activities accordingly into three categories: for the classroom, for the profession, and at the university. Our goals were to design a program in which participants gain teaching abilities and credentials, are introduced to many of the responsibilities university faculty face, become better prepared for the challenges they will face in their future academic careers, and gain a broader understanding of how the various components of their graduate experience relate to one another in their current and future careers. When designing the program, we also considered a set of related oppositions:

o Providing structure through set program requirements while allowing flexibility and individual choice

- Balancing interdisciplinary networking outside individual departments with the need for specialized professional guidance best found within them

o Requiring a number of activities within a focused time frame while also encouraging reflection on the relative value of those experiences

- Creating a rigorous, effective program without being perceived as taking too much time away from participants' research and teaching responsibilities

In response to the challenges outlined by the reform initiatives and our program considerations, we incorporated into TPT many features 
common to existing graduate student professional development programs (Bellows, 2008; Border \& von Hoene, 2010; Palmer, 2011) that address the full scope of faculty roles and responsibilities, including an emphasis on how these responsibilities differ with institutional contexts (Goldsmith et al., 2004). Generally TPT program activities include informational workshops, practical hands-on exercises, and reflection opportunities. Workshop topics range and fit into the three broad categories. For the Classroom workshops contribute to participants' understanding of student learning and teaching improvement. Ones that fit the For the Profession category focus on other topics that help prepare doctoral students for successful graduate careers, navigating the academic job market, and transitioning to an academic career afterward. Activities in the final category, At the University, focus on life as a faculty member, and include such topics as "What is service?" or "Lessons learned my first year as a professor." The hands-on exercises and reflection opportunities also fall into the three categories, and most are common to other future faculty programs (Border \& von Hoene, 2010; Palmer, 2011). Participants, for example, must design course components including a syllabus, compose a reflective teaching statement, consult with teaching center staff on some aspect of teaching, and present research at a regional or national conference. Although we specify the type and number of activities they complete in each of these areas, such as twenty hours of workshop attendance, participants have the freedom to complete many of the activities in settings or on specific topics that fit their career goals.

Compared to similar programs, TPT is unique in several ways:

o During their first semester, participants take a six-week, noncredit seminar, Foundations of Scholarly Teaching.

o Regardless of their teaching status, participants are required to teach at least five hours, which requires those with research assistantships to seek outside opportunities to guest-lecture, lead a review session, teach at a local college, or facilitate teaching workshops.

o Participants conduct at least two informational interviews-one of a faculty member and one of a higher education administrator from UVa or a different type of institution.

o Participants are required to take on a service role in their department, at the university, or within an academic organization.

o As a capstone experience, participants write two short reflective essays exploring the most valuable things they learn during the program, placing them in the context of their own teaching or 
professional development. In these essays, participants might describe, analyze, and evaluate a teaching practice or discuss future changes they would make to a course after examining student learning or teaching practices.

Program design also strikes a balance between interdisciplinary and discipline-specific concerns. TPT participants are chosen to represent a wide range of disciplines within UVa's College of Arts and Sciences and several of its professional schools. This disciplinary diversity requires the program to be highly flexible to allow participants to complete the many program requirements in various ways. Although TPT is interdisciplinary, it is also designed to be discipline focused, delegating ultimate program advising responsibilities to participant-selected faculty advisors in their own or related disciplines. Participants choose an advisor who can offer professional advice, provide feedback on their program materials, and help the participant develop a plan to reach his or her furure career goals. This aspect of TPT allows participants to tailor the program to meet their specific professional development needs and socialize them into the specific practice of their disciplinary communities (Golde, 2011). The participant and faculty advisor decide when the participant has sufficiently met the program requirements. Integrating both interdisciplinary and disciplinary components fosters community building among program participants and networking opportunities outside departmental silos, while also offering space for individualized, discipline-based professional development mentoring.

In sum, TPT participants engage in a wide range of activities sponsored by the teaching center and other university units to help them prepare for their future academic pursuits. Working closely with their faculty advisor, participants gain teaching abilities and credentials while being introduced to many of the responsibilities that university faculty and administrators face. As the assessment data we present show, participants complete the program with a more comprehensive understanding of how the various components of their graduate experience relate to one another and are better prepared for the challenges they will face in their future careers.

\section{Participant Selection and Completion}

\section{Application Process}

The TPT program attracts graduate students curious about or planning a career in academia. During the pilot year (2005), we invited applications 
from graduate students in five Arts and Sciences departments to apply and selected thirteen. In subsequent years, we opened the applicant pool to all UVa graduate students and began selecting approximately twenty-five new participants each year. As the program matured and developed a positive reputation, the number of applications has increased, and the acceptance rate has decreased from approximately 75 percent to 40 percent.

In addition to an abridged $\mathrm{CV}$ and a signed agreement that they understand the program requirements, applicants address three questions with short narratives explaining their motivations for, level of interest in, and individual goals for the program. The selection committee bases its decisions on applicants' responses to these prompts but also considers other factors, including balance among disciplines. This process has allowed us to form a highly diverse and interdisciplinary cohort each year.

\section{Participant Pool}

To date, 192 graduate students, representing thirty-five distinct departments from the College of Arts and Sciences (CLAS) and three of UVa's professional schools (Curry School of Education, EDUC; School of Engineering and Applied Sciences, SEAS; and School of Nursing, NURS), have participated in TPT. The overall participant distribution across broad disciplinary groupings is shown in table 15.1. The majority of participants (68.2 percent) come from CLAS. Within CLAS, participants

\section{Table 15.1 Overall and Gender-Separated Participant Distributions across Broad Disciplinary Groupings}

\begin{tabular}{|c|c|c|c|c|c|c|c|}
\hline & \multicolumn{3}{|c|}{ CLAS } & \multicolumn{4}{|c|}{ Professional Schools } \\
\hline & $\begin{array}{c}\text { Science } \\
\text { and } \\
\text { Math }\end{array}$ & Humanities & $\begin{array}{l}\text { Social } \\
\text { Science }\end{array}$ & SEAS & NURS & EDUC & Total \\
\hline $\begin{array}{l}\text { Total } \\
\text { participants }\end{array}$ & $55(28.6)$ & $41(21.4)$ & $35(18.2)$ & $48(25.0)$ & $7(3.6)$ & $6(3.1)$ & 192 \\
\hline $\begin{array}{l}\text { Total female } \\
\text { participants }\end{array}$ & $38(19.8)$ & $30(15.6)$ & $22(11.5)$ & $25(13.0)$ & $7(3.6)$ & $4(2.1)$ & $126(65.6)$ \\
\hline $\begin{array}{l}\text { Total male } \\
\text { participants }\end{array}$ & $17(8.9)$ & $11(5.7)$ & $13(6.8)$ & $23(12.0)$ & $0(0.0)$ & $2(1.0)$ & $66(34.4)$ \\
\hline
\end{tabular}

Note: Numbers in parentheses are percentages with respect to the total number of program participants $(N=192)$. 
are more likely to come from science and math disciplines (42.0 percent) than humanities ( 32.3 percent) and social science ones (26.7 percent). Graduate students from SEAS account for 25.0 percent of participants. NURS and EDUC round out the TPT participant pool, accounting for 3.6 and 3.1 percent, respectively. These percentages are consistent with overall graduate enrollment figures at UVa. The combined current doctoral enrollments from these four schools is approximately 2,371 graduate students, comprising 70.6 percent from CLAS, 17.5 percent from SEAS, 1.9 percent from NUC, and 10.0 percent from EDUC (UVa Office of Institutional Assessment and Studies, 2012a). Comparing these enrollments figures with program participation, we see slight underrepresentation from CLAS and EDUC and overrepresentation from SEAS and NURS.

While tracking participation along disciplinary lines, we have noticed unexpected trends related to gender. Curiously, female graduate students make up 65.6 percent of the total TPT participant pool and are two to three times more likely to participate in the program than their male counterparts in almost every disciplinary grouping. In CLAS, where overall enrollments are nearly gender equal, we see a 69:31 split favoring female participation in TPT. In SEAS, where overall enrollments are consistently skewed toward male students (29:71), we see a genderneutral distribution $(52: 48)$ in TPT. Although the female-to-male ratio here is essentially equal, TPT still oversamples the female population significantly when the overall enrollment numbers are considered. The reason for these imbalances is unclear, whether due to institutional or department cultures, some aspect of the application process, or even gender-related stereotyping or patterns of behavior on the part of applicants or their advisors. To the best of our knowledge, there is no reference in the literature to gendered participation trends in graduate student professional development programs, an area where additional research is warranted.

To make sure the selection process is not selectively biased toward female participants, we examined the gender composition of the entire applicant pool. We find that the gender distributions for the portion of the TPT applicant pool not accepted into the program are nearly identical to that of the participant pool; of those who applied but were not accepted, 60 percent were female and 40 percent were male. This suggests that the overall participant profile of TPT is representative of the applicant pool. The only notable exceptions are NURS and EDUC, where students in these disciplines make up 9.5 and 11.9 percent of the rejection pool, respectively, but only 3.6 and 3.1 percent of the participant pool. 


\section{Program Completion}

To date, 83 of the 192 TPT participants (43.2 percent) have completed all program requirements. Of these, 59 are female $(71.2$ percent) and 24 are male (28.9 percent). On average, it takes participants 2.35 years to complete all program requirements, although 3 have completed it in as few as one year and 6 have taken as many as four to five years.

Forty-six participants ( 24.0 percent) left the program without finishing: 27 women ( 58.7 percent) and 19 men ( 41.3 percent). These participants typically leave in the first year of the program for a number of reasons, most commonly citing an immediate job offer. Other reasons are changes in career path, discontinuation of doctoral studies, and work/life balance issues.

Currently, 63 participants remain active in the program- 40 women (63.5 percent) and 23 men ( 36.5 percent) - which mirrors the female-tomale ratio observed for the overall participant pool. One might expect that the completion and exit distributions would also mirror the makeup of the overall participant pool. We see, however, that female participants are slightly more likely to complete the program compared to male participants. Again, the reasons behind this observation are not clear and warrant additional research to tease out the underlying causes.

\section{Assessment}

In 1999 the Survey on Doctoral Education and Career Preparation was prepared for the Pew Charitable Trust (Golde \& Dore, 2001). Among other topics, the survey explored how effectively doctoral programs prepare students for various teaching, research, and service activities. Beginning with a subset of these questions, we created a TPT-specific survey to measure participants' perceptions about preparedness in twenty-one areas typically associated with junior faculty responsibilities. Participants complete the survey prior to entering our program and again after completing all requirements. We currently have preprogram surveys from 179 of the 192 TPT participants (93.2 percent response rate) and exit surveys from 62 of the 89 who have successfully completed the program (69.7 percent response rate).

We compare the TPT program assessment data to several baseline surveys:

o 2008 UVa Graduate Student Survey (UVa Office of Institutional Assessment and Studies, 2012b). We administered our TPT survey to a random sample of graduate students across all schools at $\mathrm{UVa}$; 
611 students responded to the survey (43.3 percent response rate). At a 95 percent confidence level, the overall sampling error for the survey was \pm 2.6 percent. Results from this survey will henceforth be identified as UVaGrad.

○ 1999 Survey on Doctoral Education and Career Preparation (Golde \& Dore, 2001). Over four thousand third-year or later graduate students from twenty-seven universities in eleven arts and sciences disciplines participated in the survey ( 42.3 percent response rate). Results from this survey will henceforth be identified as PEW.

- 2007 Survey of Perceptions of Early Career Faculty (Berberet, 2008). A study sponsored by the TIAA-CREF Institute surveyed 450 junior faculty from Associated New American Colleges in their first five years ( 33.9 percent response rate) about their graduate preparation. Results from this survey will henceforth be identified as TIAA-CREF.

0 The pre- and post-TPT surveys will henceforth be identified as preTPT and post-TPT, respectively.

Tables 15.2 to 15.4 show respondents' perceptions of preparedness in teaching-, research-, and service-related activities for each of the three baseline surveys-PEW, TIAA-CREF, and UVaGrad-as well as perceptions of TPT participants before and after program participation. (In order to determine statistically significant differences between the preTPT and post-TPT survey data, we conducted independent $t$-tests for each of the twenty-one survey items. This analysis revealed that students completing the TPT program are statistically significantly more able to navigate university or college administration at the conclusion of the program $(t(56) 1.094, p=.031)$. Although we found significant differences for only one item, due to the nature of the survey data (differing pre- and postsample sizes, anonymous survey data collection) and the qualitative nature of the study, we think that inferential statistical analysis is not the best method for displaying or communicating the findings of this survey. Only respondents reporting that they felt "very prepared" for the various competencies are shown in the tables. Competency areas not addressed in the PEW and TIAA-CREF surveys are noted with a dash.

\section{Teaching-Related Competencies}

The survey data for the seven teaching-related competencies tracked are shown in table 15.2. In general, despite some variation, the baseline survey data show relatively comparable levels of preparedness across 
Table 15.2 Percentage of Survey Respondents Indicating They Felt "Very Prepared" for Teaching-Related Competencies Associated with Typical Faculty Positions

\begin{tabular}{|c|c|c|c|c|c|}
\hline & $\begin{array}{c}\text { PEW } \\
(n=4,114)\end{array}$ & $\begin{array}{l}\text { TIAA-CREF } \\
(n=450)\end{array}$ & $\begin{array}{l}\text { UVaGrad } \\
(n=611)\end{array}$ & $\begin{array}{c}\text { Pre-TPT } \\
(n=179)\end{array}$ & $\begin{array}{l}\text { Post-TPT } \\
(n=62)\end{array}$ \\
\hline $\begin{array}{l}\text { Design an } \\
\text { independent } \\
\text { course }\end{array}$ & - & - & 23.2 & 12.8 & 62.9 \\
\hline $\begin{array}{l}\text { Teach an } \\
\text { independent } \\
\text { course }\end{array}$ & - & 31 & 29.7 & 21.2 & 74.2 \\
\hline $\begin{array}{l}\text { Teach a } \\
\quad \text { specialized } \\
\text { graduate } \\
\text { course }\end{array}$ & 23.3 & - & 15.3 & 5.0 & 46.8 \\
\hline $\begin{array}{l}\text { Integrate } \\
\text { research and } \\
\text { teaching }\end{array}$ & & & 17.0 & 5.0 & 46.8 \\
\hline $\begin{array}{l}\text { Incorporate } \\
\text { technology } \\
\text { in the } \\
\text { classroom }\end{array}$ & 14.1 & 20 & 32.8 & 21.2 & 46.8 \\
\hline $\begin{array}{l}\text { Develop a } \\
\text { teaching } \\
\text { portfolio }\end{array}$ & 26.6 & 19 & 14.7 & 7.8 & 69.4 \\
\hline $\begin{array}{l}\text { Manage } \\
\text { teaching } \\
\text { assistants }\end{array}$ & - & - & 22.1 & 20.7 & 50.0 \\
\hline
\end{tabular}

the competencies. A particularly interesting comparison is between the pre-TPT data and the UVaGrad data. In all competencies but one, the preTPT data are lower than the UVaGrad data, meaning that entering TPT participants feel less prepared than the average UVa graduate student to meet teaching expectations. This feeling of unpreparedness is consistent with program application data, which show the primary reason graduate students want to join TPT is to improve their teaching knowledge and capabilities.

The differences between pre- and post-TPT perceptions of preparation are striking and range from students feeling two to as many as nine times more prepared after participation in TPT. The most notable gains are in the areas of designing and teaching independent courses and developing a 
teaching portfolio. This finding seems logical, because these participants have repeated exposure to and practice in these three areas through multiple TPT activities, including the pedagogy seminar, syllabus and reflective teaching statement workshops, and the course development and classroom teaching components.

The large perceptual gains observed for the teaching-related competencies are consistent with the fact that the number and variety of teaching-related program activities far outnumber other professional development activities. The program places emphasis on teaching partly because TPT is offered through UVa's teaching center, but mostly because junior faculty consistently list this as the area they need most help with during their early-career years (Golde \& Dore, 2001; Berberet, 2008). The gains are also likely related to participants' interest in the teaching aspects of the program, as indicated by their survey responses: 92.9 percent of participants claim their interest in a faculty position is due to their "enjoyment of teaching," while only 64.1 percent say "enjoyment of research" draws them to such a career.

\section{Research-Related Competencies}

The survey data for the seven research-related competencies tracked are shown in table 15.3. Other than the PEW survey data showing a relatively high number of respondents who felt very prepared for conducting and

Table 15.3 Percentage of Survey Respondents Indicating They Felt "Very Prepared" for Research-Related Competencies Associated with Typical Faculty Positions

\begin{tabular}{|c|c|c|c|c|c|}
\hline & $\begin{array}{c}\text { PEW } \\
(n=4,114)\end{array}$ & $\begin{array}{c}\text { TIAA- } \\
\text { CREF } \\
(n=450)\end{array}$ & $\begin{array}{l}\text { UVaGrad } \\
(n=611)\end{array}$ & $\begin{array}{c}\text { Pre-TPT } \\
(n=179)\end{array}$ & $\begin{array}{c}\text { Post- } \\
\text { TPT } \\
(n=62)\end{array}$ \\
\hline Conduct research & 65.1 & 33.0 & 40.1 & 40.8 & 79.0 \\
\hline Publish research & 42.9 & - & 24.1 & 22.3 & 56.5 \\
\hline Present research & - & - & 37.9 & 47.5 & 85.5 \\
\hline $\begin{array}{l}\text { Collaborate in } \\
\text { interdisciplinary } \\
\text { research }\end{array}$ & 27.1 & 25.0 & 23.7 & 23.5 & 53.2 \\
\hline $\begin{array}{l}\text { Obtain research } \\
\text { funding }\end{array}$ & - & 7.0 & 6.3 & 7.3 & 22.6 \\
\hline $\begin{array}{l}\text { Develop a writing } \\
\text { habit }\end{array}$ & - & - & 22.8 & 14.0 & 50.0 \\
\hline
\end{tabular}


publishing research, the results across the three baseline surveys are again roughly comparable. The UVaGrad survey data, in particular, are within a few percentage points of the pre-TPT data for most competencies, suggesting that the entering TPT participant pool is generally representative of the UVa graduate student population. Two notable exceptions are in the areas of presenting research and developing a writing habit. In the case of presenting research, TPT participants feel more prepared than other UVa graduate students. Because the UVaGrad survey included firstyear graduate students and TPT is restricted to second-year students and up, it would make sense that TPT participants feel more prepared for presenting research than the general graduate student population simply because they have had more opportunities to do so. Year in program may also explain why respondents to the PEW survey-students in their third year and up-feel considerably better prepared to conduct and publish research than respondents of all the other surveys. If, however, academic level alone accounts for these differences, it is unclear why TPT participant responses do not align more closely with the PEW survey respondents. In the case of developing a writing habit, TPT participants feel less prepared than the UVaGrad respondents. Again, if academic level were to account for TPT participants' perceptions, one would expect the value to be higher, suggesting some other factor is at play. It may be that the UVaGrad and TPT respondents are inherently different in their preparation for these areas or that something about the TPT program is selecting out a unique population.

Though not as dramatic an increase as seen for teaching competencies, the post-TPT survey data show that graduate students who complete the TPT program are still roughly two to three times more likely to feel very prepared for each of the seven research-related competencies than when they entered the program. The question is whether these perceptual gains are developmental or a result of program participation. Since graduate programs traditionally emphasize research training (Golde \& Dore, 2001), one could reasonably expect students, including those participating in TPT, to feel more prepared to do research as their studies progress. Though progress toward degree may be responsible for some of the gain, it does not appear to account for the magnitude of the shifts in most areas. If it did, one would expect a better correlation between the PEW respondents-composed of graduate students in their third year and beyond-and the post-TPT respondents-composed of students in their fourth year and up. In other words, it appears that aspects of the TPT program cause an increase in participants' perceptions of preparedness beyond developmental gains. This could stem from the minimal 
requirements of attending a conference and presenting research at a scholarly venue, from increased confidence produced by effective mentoring or the process of creating competitive job materials, or even from norming comparisons with peers in other disciplines. TPT participants report benefiting as well from occasional workshops on topics such as getting published and grant writing.

\section{Service-Related Competencies}

Survey data for the seven service-related competencies tracked are shown in table 15.4. Except for the TIAA-CREF data, the baseline surveys compare reasonably well. Few TIAA-CREF respondents reported feeling very prepared for service on academic committees and advising undergraduate students. This may be due to the type of institution the Associated New American Colleges faculty come from (e.g., midsize private Carnegie Master's) or because the realities of committee work and advising are considerably more demanding than expected by graduate students.

Table 15.4 Percentage of Survey Respondents Indicating They Felt "Very Prepared" for Service-Related Competencies Associated with Typical Faculty Positions

\begin{tabular}{|c|c|c|c|c|c|}
\hline & $\begin{array}{c}\text { PEW } \\
(n=4,114)\end{array}$ & $\begin{array}{c}\text { TLAA- } \\
\text { CREF } \\
(n=450)\end{array}$ & $\begin{array}{l}\text { UVaGrad } \\
(n=611)\end{array}$ & $\begin{array}{l}\text { Pre-TPT } \\
(n=179)\end{array}$ & $\begin{array}{c}\text { Post- } \\
\text { TPT } \\
(n=62)\end{array}$ \\
\hline $\begin{array}{l}\text { Serve on university } \\
\text { or departmental } \\
\text { committees }\end{array}$ & - & 10 & 13.2 & 16.8 & 37.1 \\
\hline $\begin{array}{l}\text { Referee academic } \\
\text { papers }\end{array}$ & - & - & 10.1 & 16.8 & 37.1 \\
\hline $\begin{array}{l}\text { Advise } \\
\text { undergraduates }\end{array}$ & 26.8 & 8 & 30.2 & 22.3 & 61.3 \\
\hline $\begin{array}{l}\text { Advise graduate } \\
\text { students }\end{array}$ & 16.5 & - & 10.1 & 9.5 & 30.6 \\
\hline $\begin{array}{l}\text { Navigate university } \\
\text { or college } \\
\text { administration }\end{array}$ & - & - & 7.4 & 3.4 & 25.8 \\
\hline $\begin{array}{l}\text { Understand tenure } \\
\text { and promotion } \\
\text { processes }\end{array}$ & - & - & 2.7 & 0.0 & 11.3 \\
\hline $\begin{array}{l}\text { Balance work and } \\
\text { personal time }\end{array}$ & - & - & 19.7 & 10.1 & 40.3 \\
\hline
\end{tabular}


Again, entering TPT participants report feeling less prepared for service-related activities than students in the other survey pools. In fact, nearly 10 percent fewer TPT participants feel very prepared for each of the competencies compared to $\mathrm{UVaGrad}$ respondents. The gains observed post-TPT are likely due to targeted programming in a number of servicerelated areas, typically through workshops or panel sessions, such as a biennial panel discussion on understanding tenure and promotion at a variety of institution types.

Among all the competency categories, students clearly feel least prepared to engage in service-related activities, even after completing TPT. Informed by this data, we added programming to address related competencies. In addition to existing workshops defining service roles, we recently included a new program requirement: TPT participants must serve on a committee within their department, the university, or a professional disciplinary organization. We expect perceptions of preparednessand actual preparedness-to continue to increase.

\section{Career Interests}

The TPT-specific surveys also ask participants about their career interests. When entering the program, 51.9 percent of participants are interested in positions at research-focused universities, 40.0 percent at teachingfocused institutions, and the remainder ( 8.1 percent) in a variety of nonfaculty positions in business, government, and nonprofits. After leaving the program, interest in positions at research-focused universities drops to 35.5 percent and interest in positions at teaching-focused institutions drops to 25.8 percent, while interest in nonfaculty positions increases to 38.7 percent. Nonfaculty positions identified include college administration and other alternative academic careers; research and management positions in private, nonprofit or government sectors; and independent consulting. A 2007 survey of graduate students at University of California (UC) campuses $(N=8,400)$ mirrors these shifts (Mason, Goulden, \& Frasch, 2009). The UC investigators found that from the start of students' doctoral programs to the time of the survey, interest in research-focused faculty positions declined from 41.9 to 31.3 percent, interest in teaching-focused positions remained relatively unaffected at approximately 23.5 percent, and interest in nonfaculty positions increased from 32.5 to 41.9 percent. Notably, TPT participants' initial interests in research- and teaching-focused positions are considerably higher than the UC sample. This is likely due to TPT participants' selfselection into a program focused on preparing future faculty. As TPT 
Table 15.5 UVaGrad and Pre- and Post-TPT Survey Respondents' Perceptions of Preparation for Applying Immediately to Faculty Positions

$$
\begin{aligned}
& \text { UVaGrad } \\
& (n=611)
\end{aligned}
$$

Very prepared Somewhat prepared Not prepared
9.3

39.4

51.3

$$
\begin{aligned}
& \text { Pre-TPT } \\
& (n=184)
\end{aligned}
$$

43.0

53.1
Post-TPT

$(n=62)$

48.4

48.4

1.6

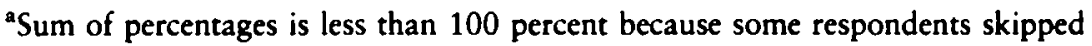
this question.

participants finish the program, however, their career interests are nearly identical to the UC sample, suggesting that factors beyond the scope of TPT are affecting career interests.

\section{Preparation for the Job Market}

In the UVaGrad, pre-TPT, and post-TPT surveys, respondents were asked: "If you were to go on the job market today, how prepared are you to apply for faculty positions?" The response data are shown in table 15.5. Here again, we see that entering TPT participants' perceptions of preparedness mirror those of the general UVa graduate student population. On completion, however, over 98 percent of TPT participants feel very or somewhat prepared compared to fewer than 50 percent for the average UVa graduate student, suggesting that the program meets this immediate need of participants.

Although perceptions of preparedness for the job market are encouraging, these data do not clarify how successful TPT participants are in their search for faculty positions, for those who seek them, or their eventual success in such positions. Several researchers have suggested that graduate student activities that align well with competencies developed by successful junior faculty have the most positive impact on their professional development (Austin \& McDaniels, 2006; Seldin, 2006; Bellows, 2008; Smith \& Simpson, 1995; Schönwetter \& Ellis, 2011; Walker et al., 2008), yet measures of long-term, causal impact from these sorts of broad professional development programs are relatively scarce in the literature (Border, 2006; DeNeef, 2002; Kalish et al., 2011; Marincovich, Prostko, \& Stout, 1998; Taylor, Schönwetter, Ellis, \& Roberts, 2008).

In spring 2011, we began investigating the long-term impact of TPT by extending our assessment of the program to include interviews from 
participants who had obtained faculty $(n=14)$ and postdoctoral $(n=6)$ positions (Little, Palmer, Hurst, \& Maher, 2011). Initial analysis of the data in this IRB-approved study confirms long-term benefits of the program. For example, participants who are now teaching reported that mastering classroom instruction before they began their current position was invaluable. Representative comments included, "For me, it [TPT participation] was the only teaching preparation I had for my role... The knowledge and skills related to teaching that I gained from the workshops... were extremely beneficial" (nursing faculty); "I use the skills from the [teaching] workshops all the time" (biology faculty). We are finding comparable trends in other competency areas and are actively pursuing research to better measure long-term impact.

\section{Summary}

Based on a recently published taxonomy of graduate professional development programs, UVa's Tomorrow's Professor Today program is defined as a professional and teaching development program with a broad scope that requires high participant commitment (Palmer, 2011). Through a variety of activities, participants prepare for a suite of responsibilities junior faculty face. Ongoing assessment of TPT shows sizable gains in participants' perceptions of preparedness in twenty-one teaching-, research-, and services-related competencies tracked throughout the first eight years of the program. These gains are observed even when only limited programming is offered in competency areas, which suggests that the structure of the program not only gives participants knowledge of how to address different competencies but also provides the flexibility necessary for each participant to meet specific professional development needs. On the strength of participants' perception data alone, one could conclude that the TPT program is having a significant effect on preparing future faculty. Through follow-up interviews with former participants who have since taken faculty positions, we are beginning to see evidence of positive, long-term effects.

\section{REFERENCES}

Adams, K. A. (2002). What colleges and universities want in new faculty. Washington, DC: Association of American Colleges and Universities. Retrieved from hrtp://www.aacu.org/pff/pdfs/PFF_Adams.PDF

Austin, A. E. (2002). Preparing the next generation of faculty. Journal of Higher Education, 73(1), 94-122. 
Austin, A. E., \& McDaniels, M. (2006). Preparing the professoriate of the future: Graduate student socialization for faculty roles. In J. C. Smart (Ed.), Higher education: Handbook of theory and research, Vol. 21 (pp. 397-456). Netherlands: Springer.

Austin, A. E., \& Wulff, D. H. (2004). The challenge to prepare the next generation of faculty. In D. Wulff \& A. Austin (Eds.), Paths to the professoriate. San Francisco, CA: Jossey-Bass.

Bellows, L. (2008). Graduate student professional development: Defining the field. In L.L.B. Border (Ed.), Studies in graduate and professional student development: Vol. 11. Defining the field (pp. 2-17). Stillwater, OK: New Forms Press.

Berberet, J. (2008). Perceptions of early career faculty: Managing the transition from graduate school to professorial career. TIAA-CREF Institute: Research Dialogue. Retrieved from http://www.tiaa-crefinstitute.org/institute /research/dialogue/rd_92.html

Border, L.L.B., \& von Hoene, L. M. (2010). Graduate and professional student development programs. In K. J. Gillespie \& D. L. Robertson (Eds.), A guide to faculty development (2nd ed.). San Francisco, CA: Jossey-Bass.

DeNeef, A. L. (2002). The preparing future faculty program: What difference does it make? Washington DC: American Association of Colleges and Universities.

Fagan, A., \& Suedkamp Wells, K. M. (2004). The 2000 National Doctoral Program survey: An on-line study of students' voices. In D. H. Wulff \& A. E. Austin (Eds.), Paths to the professoriate. San Francisco, CA: JosseyBass.

Gaff, J. G. (2002). The disconnect between graduate education and the realities of faculty work: A review of recent research. Liberal Education, 88(3), 6-13.

Gaff, J. G., Pruitt-Logan, A. S., \& Weibl, R. A. (2000). Building the faculty we need: Colleges and universities working together. Washington, DC: Association of American Colleges and Universities and the Council of Graduate Studies.

Golde, C. (2011). Entering different worlds: Socialization into disciplinary communities. In S. K. Gardner \& P. Mendoza (Eds.), On becoming a scholar: Socialization and development in doctoral education (pp. 79-95). Sterling, VA: Stylus.

Golde, C. M., \& Dore, T. M. (2001). At cross purposes: What the experiences of doctoral students reveal about doctoral education. Retrieved from http:// www.phd-survey.org/reportpercent20final.pdf

Goldsmith, S., Haviland, D., Daily, K., \& Wiley, A. (2004). Preparing future faculty initiative: Final evaluation report. Retrieved from http://www.aacu .org/pff/pdfs/PFF_Final_Report.pdf 
Kalish, A., Robinson, S., Border, L.L.B., Chandler, E. O., Connolly, M., Eaton, L. J., . . \& von Hoeneer, L. (2011). Steps toward a framework for an intended curriculum for graduate and professional students: How we talk about what we do. Studies in graduate and professional student development: Vol. 14. Mapping the range of graduate student professional development (pp. 163-173). Stillwater, OK: New Forms Press.

Little, D., Palmer, M., Hurst, M., \& Maher, M. A. (2011). Investigating the longterm impact of a graduate student future faculty program. Paper presented at the 2011 Conference on Higher Education Pedagogy, Blacksburg, VA.

Marincovich, M., Prostko, J., \& Stout, F. (Eds.). (1998). The professional development of graduate teaching assistants. Bolton, MA: Anker.

Mason, M. A., Goulden, M., \& Frasch, K. (2009). Why graduate students reject the fast track. Academe, 95, 11-16.

Nyquist, J., \& Woodford. B. (2000). Re-envisioning the Ph.D. What concerns do we have? Seattle: University of Washington, Center for Instructional Development and Research. Retrieved from http://depts.washington.edu lenvision/resources/ConcernsBrief.pdf

Palmer, M. S. (2011). Graduate Student Professional Development: A Decade after Calls for National Reform. In L.L.B. Border (Ed.), Studies in graduate and professional student development: Vol. 14. Mapping the range of graduate student professional development (pp. 1-17). Stillwater, OK: New Forms Press.

Schönwetter, D. J., \& Ellis, D. E. (2011). Taking stock: Contemplating North American graduate student professional development programs and developers. In J. E. Miller \& J. E. Groccia (Eds.), To improve the academy: Resources for faculty, instructional, and organizational development, Vol. 29. San Francisco: Jossey-Bass.

Seldin, P. (2006). Tailoring faculty development programs to faculty career stages. In S. Chadwick-Blossey \& D. R. Robertson (Eds.), To improve the academy: Resources for faculty, instructional, and organizational development, Vol. 24. Bolton, MA: Anker.

Smith, K. S., \& Simpson, R. D. (1995). Validating teaching competencies for faculty members in higher education: A national study using the Delphi method. Innovation in Higher Education, 19, 223-233.

Taylor, K. L., Schönwetter, D. J., Ellis, D. E., \& Roberts, M. (2008). Profiling an approach to evaluating the impact of two certification in university teaching programs for graduate students. In L.L.B. Border (Ed.), Studies in graduate and professional student development: Vol. 11. Defining the field (pp. 4575). Stillwater, OK: New Forms Press

University of Virginia, Office of Institutional Assessment and Studies. (2012a). Data digest: Admission. Retrieved from http://avillage.web.virginia.edu /iaas/instreports/studat/dd/adm_grad.htm 
University of Virginia, Office of Institutional Assessment and Studies. (2012b). Graduate professional development survey. Retrieved from http:/avillage .web.virginia.edu/iaas/survey/portal/2008-09/08graduatedev.shtm

Walker, G. E. (2004). The Carnegie initiative on the doctorate: Creating stewards of discipline. In D. H. Wulff \& A. E. Austin (Eds.), Paths to the professoriate. San Francisco, CA: Jossey-Bass.

Walker, G. E., Golde, C. M., Jones, L., Bueschel, A. C., \& Hutchings, P. (2008). The formation of scholars: Rethinking doctoral education for the twentyfirst century. San Francisco, CA: Jossey-Bass.

Wulff, D. H., \& Austin, A. E. (2004). Paths to the professoriate. San Francisco, CA: Jossey-Bass. 